There is good reason for believing that such an international conference will be arranged, and its action should be of great benefit to the mercantile marines of the world, which are and will remain necessarily in competition with one another, but should not carry on that competition in a manner likely to be prejudicial to the safety of life and property at sea. If the loss of the Titanic should bring about a better understanding and the universal acceptance of principles which will add to the security of ocean navigation, the lessons learnt from that terrible disaster will be of permanent value.

\section{THE DISCOVERY OF HUMAN REMAINS AT CUZCO, PERU.}

THE Yale expedition to Peru has made an important discovery of human remains in the vicinity of Cuzco, which are described in the April number of the American Journal of Science. We have, first, a full report of the circumstances of the "find" by the director of the expedition, Mr. Hiram Bingham. Following this, Mr. I. Bowman contributes a very cautious and wellconsidered report on the geological position. He comes to the conclusion that the beds in which the remains were found belong to a glacial series; that the bones were deposited during a period of pronounced alluviation; that since their deposition they were overlaid by from 75 to roo $\mathrm{ft}$. of gravel, and were at a later period partially eroded. Though at first sight the immediate surroundings suggest the occurrence of a landslip, this view does not commend itself to him, and he provisionally estimates the age of the remains at from 20,000 to 40,000 years.

The anatomical material consists of fragments of a cranium, portions of ribs, the right os innominatum, one complete and one imperfect femur. Mr. G. F. Eaton's report indicates that this femur falls within the range of femoral variation in normal male adult Peruvians of the later Inca period. The remains were accompanied by a portion of the tibia of a wolf or wolf-like dog, closely resembling a small gray wolf, Canis occidentalis. It may be remarked that three varieties of breeds of domestic dogs are known to have existed in Peru during the later Inca period-a small-sized breed of the bulldog or pug type, with a short snout and undershot jaw; a small housedog like the dachshund, with slender snout; and a larger, slender-limbed variety, with wolf-like skull, originally classed by Tschudi under the name Canis ingae pecuarius. The two latter types are supposed to be descended from a larger wolf-like variety, itself derived from the American wolf. Thus the presence in this site of a large wolf-like dog, while it offers in itself no proof of great antiquity, does not render that supposition untenable.

But, besides the canine remains, those of what seems to be a bison have also been found; the study, however, of these rib fragments cannot differentiate the bison from domestic cattle.
According to Mr. Eaton, if the Cuzco remains date from $\dot{a}$ period preceding the Spanish Conquest, it would appear that the bovine remains belong to some species of bison, for no other feral group of the bovidæ need be considered. The difficulty remains that though the Spaniards found captive bison at Montezuma's capital, the American bison in the free state is not known to have ranged further south than north-eastern Mexico.

The existence, therefore, of the associated canine and bovine remains raises considerations not easily reconciled with the geological environment, and for the present the exact age of the Cuzco remains must continue to some extent to be uncertain. It is much to be desired that further examination of this promising site may lead to the discovery of further evidence on which a final decision may be safely based.

THE LATE MR. A. O. HUME, C.B.

M R. ALLAN OCTAVIAN HUME, whose I death took place at his residence in Upper Norwood on July $3 \mathrm{I}$, at the age of eighty-three, ranks as one of the chief benefactors to the natural history departments of the British Museum. During the latter portion of his career ( 1849 to 1882 ) as a Bengal civilian, the deceased gentleman devoted his leisure and much of his fortune to collecting skins and eggs of Indian birds and heads of Indian big game. The result was the bringing together of a collection such as had never been made before, including, as it did, not only specimens obtained by himself and his assistant, Mr. W. R. Davison, but many purchased from other collections. Except for a selection of specimens-chiefly big game-retained for his own lifetime, but ultimately to come, we believe, to the nation, this collection was presented to the British Museum between $188_{5}$ and I 891 . Previous to this the Museum collection of Indian birds was poor, whereas now it is surpassingly rich.

The total number of skins and eggs of birds added to the Museum collection was 75,577 , of which $25^{8}$ were types. The big-game collection comprised 223 specimens, in addition to which were $37 \mathrm{I}$ mammal skins, including several types.

Mr. Hume started and for fifteen years maintained Stray Feathers, and was also author or coauthor of several other works on Indian ornithology. To kind attention received in the 'seventies at Mr. Hume's Simla residence, the present writer owes his recovery from severe illness. $R$. L.

\section{NOTES.}

ThE second International Congress of Entomology was opened at Oxford on Monday last, under the presidency of Prof. E. B. Poulton, F.R.S., and is still in progress.

A committee has been appointed by the President of the Board of Trade to advise him, in the interests of safety of life at sea, with regard to methods of stowing, launching, and propelling ships' boats, and other kindred matters. Prof. J. H. Biles is the chairNO. 2232 , VOI.. 89] 